Article

\title{
Emission Tax and Compensation Subsidy with Cross-Industry Pollution
}

\author{
Kuang-Feng Cheng ${ }^{1}$, Chien-Shu Tsai ${ }^{2, *}$, Chu-Chuan Hsu ${ }^{3, *}$, Szu-Chung Lin ${ }^{4}$, \\ Ting-Chung Tsai ${ }^{1}$ and Jen-Yao Lee ${ }^{1}$ \\ 1 Department of International Business, National Kaohsiung University of Science and Technology, \\ Kaohsiung City 80778, Taiwan; beefeng5524@gmail.com (K.-F.C.); caidinzhon@gmail.com (T.-C.T.); \\ itjylee@kuas.edu.tw (J.-Y.L.) \\ 2 Department of Tourism Management, Kao Yuan University, Kaohsiung City 82146, Taiwan \\ 3 Department of Marketing and Logistics Management, Yu Da University of Science and Technology, \\ Miaoli County 36143, Taiwan \\ 4 School of Management and Economics, Kunming University of Science and Technology, \\ Kunming 650093, China; sclin777@gmail.com \\ * Correspondence: cstsai@xhome.com.tw (C.-S.T.); edison9@ydu.edu.tw (C.-C.H.)
}

Received: 16 January 2019; Accepted: 12 February 2019; Published: 15 February 2019

check for updates

\begin{abstract}
This paper establishes a cross-industry pollution externality model. To explain a benevolent government, it may be possible to tax part of the welfare gains and use the revenue to compensate the affected polluted industry for the damage cost, thereby improving welfare. We show that the social welfare under emission tax with production subsidy is higher than the results of emission tax without production subsidy. The welfare of the polluted sector under emissions trading will be lower than the results of unbalanced budget environmental policy with subsidy. The welfare of the polluted labor union under lobby for compensation will be higher than the results of environmental policy with subsidy if the pollution damage and the weight on political contributions are sufficiently high.
\end{abstract}

Keywords: production externality; productivity of labor; emission tax; labor subsidy

\section{Introduction}

In recent years, cross-border and cross-industry pollution of air, water and soil has become the focus of environmental issues. According to the European Environment Agency (EEA) report, about 422,000 people died prematurely in European countries in 2015 due to exposure to harmful levels of fine particulate matter (PM2.5) [1]. The scientific evidence of the effects of PM pollution on human health is validated by numerous epidemiological, biological, and pathological studies [2-10]. In China, PM2.5 pollution is a critical environmental problem, causing approximately 1.37 million premature deaths yearly [11-13]. The Pearl River Delta (PRD) region is one of the fastest growing regions in China and has experienced serious air pollution issues because of its highly intensive energy consumption, which causes high levels of air pollution emissions. PRD continues to suffer from a high number of PM2.5 events and resultant public health impacts. Outdoor PM2.5 pollution has caused 20,160 premature mortalities every year in the PRD region [14]. Similarly, the poor indoor air quality in public places (e.g., offices, homes, schools, and stations) is harmful to public health, and several studies have indicated that most of these sites may have significant adverse effects on human health $[7,15,16]$. It can be understood that environmental pollution may affect the marginal productivity of the labor force, thereby reducing the competitiveness of environmentally sensitive industries.

Since 1990, the EU has seen a general decoupling of economic growth from greenhouse gas emissions, driven mainly by emission reductions from industrial and power plants covered under 
the EU emissions trading system, milder winters and reduction in oil consumption for transport [17]. Overall, current energy industries are by far the largest source of emissions in the EU, accounting for about 33 percent of the total in 2011 (the last year for which official UNFCCC data is available), followed by the transport sector (21\%) and manufacturing and construction $(20 \%)$ [18]. The pollution caused by related industries is generally valued. The impact on environmental quality has always been one of the important policies of governments.

In the EU, emission control regulations mainly focus on the air, water and soil quality. For example, the main instruments of the EU policy on air pollution are the New Air Quality Directive (2008/50/EC) and the National Emission Ceilings Directive (2001/81/EC). Moreover, other legal instruments have been used to minimize air pollution (e.g., Council Directive 96/62/EC, Directive 2004/107/EC, and Commission Decision 2004/461/EC). The New Air Quality Directive is aimed to merge the existing legislation into a single directive. The latter also introduces new objectives for PM2.5 as the limited-value objective, the exposure-related objective, the exposure concentration obligation, and the exposure reduction target. Moreover, EU States are required to reduce the PM2.5 exposure of the population to an annual average limit of $20 \mu \mathrm{g} / \mathrm{m}^{3}$ by 2020 [19].

In Europe, air pollution has significant impacts on human health (i.e., reduction of life expectancy) and the economy (i.e., increase of medical costs and reduction of productivity). The EEA document highlights that in large European regions, the limit values for PM10 were still exceeded in 2013. In particular, the PM10 daily limit value was regularly exceeded in Italy, Poland, Bulgaria, Slovakia and the Balkan region [20].

In mid-July 2014, the EEA issued a report, arguing that "green fiscal" reforms can boost employment while protecting the environment, such as reducing taxes on labor. In turn, tax is imposed on industries that damage the environment. Hans Bruyninckx, executive director of the Environment Agency, said well-designed environmental taxes can reduce pollution and increase resource efficiency in a very cost-effective way, and at the same time promote employment, economic growth and social fairness [21].

It must be emphasized that most of the environmental policies only concern the taxation of the departments that damage the environment, and there is relatively little discussion about the negative impact of cross-industry. As mentioned above, while the government is taxing industries that damage the environment, it should not only reduce taxes, but may even subsidize industries that suffer from environmental damage.

According to the "Theory of Compensatory Principle", in the process of economic growth, social changes (production and investment behavior) will likely benefit some members and damage other members. If the beneficiaries can receive compensation for losses suffered, then this change can increase social welfare. Therefore, whether the government's environmental policy intervention can improve welfare allocation will be an important issue. Government intervention in the marketplace is often justified as a means to increase net social welfare. When imposing welfare-improving regulation, a benevolent government may be able to tax part of the welfare gains and use the revenue to compensate industry for the damage cost.

In addition, when ownership of emission rights is defined, trading through emissions rights may change the distribution of benefits in the economy. The European Union Emissions Trading System (EU ETS), the largest cap-and-trade system worldwide, imposes an overall cap on $\mathrm{CO}_{2}$ emissions from heavy energy-using installations (mostly power stations and industrial plants) and airlines operating in 31 countries (all 28 EU countries plus Iceland, Liechtenstein and Norway). Emitters with heterogeneous abatement costs can trade permits amongst each other or with third parties so as to lower their total abatement cost and hence the total cost of complying with the cap on $\mathrm{CO}_{2}$. Since the beginning of the EU ETS in 2005, industrial emitters have been compensated for the cost of compliance by receiving fairly generous allocations of free permits based on their past $\mathrm{CO}_{2}$ emissions [22,23].

Due to this, the government may reduce environment pollution but exacerbate unemployment by regulating the environment. The impact of environmental regulation policy really arouses furious 
debate; however, some researchers hold divergent opinions and have disputed how environmental limits affect employment. Some studies indicated that if the environmental tax revenues can help to reduce other distortion taxation, say labor tax, this can improve both environment and social welfare. In this paper, we show that the social welfare under emission tax with production subsidy is higher than the case of emission tax without production subsidy. The welfare of the polluted sector under emissions trading will be lower than the results of unbalanced budget environmental policy with subsidy.

The rest of the paper is organized as follows: Section 2 is the literature review; Section 3 provides model settings and benchmarks; Section 4 discusses the environmental policy with production subsidy; Section 5 discusses environmental policy with labor subsidy; Section 6 explains the policy extensions, finally followed by the conclusion.

\section{Literature Review}

Pigou [24] believes that external cost internalization is an important means of addressing environmental externalities. It is proved that in a competitive industrial structure, the optimal pollution tax rate should be equal to the marginal damage of environmental pollution. A large amount of literature has also focused on discussing environmental policies under different market structures. Simpson [25] utilized a homogeneous Cournot competition model to analyze the optimal pollution and found that if firms have different production cost, the optimal environment tax rate may be greater than the marginal environmental damage rate. Katsoulacos and Xepapadeas [26] proved that when the number of firms holds the second-best theory, the tax rate will be higher than the marginal environmental damage rate. Damania [27] established a repeated game model to analyze the incentive scheme and effects of pollution control in an oligopoly market. He found that in some cases, firms may opt not to purchase pollution control equipment, even though these devices could reduce production costs. Yin [28] suggested an oligopoly model to explore pollution taxation and externality control among firms. He found that when great externality occurs, no matter positive or negative, pollution taxation on these firms does not necessarily lead to social deadweight loss. Lahiri and Ono [29] designed an oligopoly model with produced homogeneous pollution emission, and found that when the number of firms is not changed in the short term, a relative pollution emission standard is better than that under the Pigouvian tax in the social welfare. Besides, the emission standard under the Pigouvian tax is better than the relative emission standards with equivalent welfare. However, in the long run with free entry, when the market inverse demand function is a concave one, the result is just the opposite. Cato [30] shows that if the two-part policy exists, that is, adopting optimal refund and environment pollution taxes, the first-best result can achieve without external subsidy, even though there is no free entry of firms. Fujiwara [31] constructed a heterogeneous oligopoly model to consider how the product differentiation affects the optimal pollution taxes or subsidies under limited entry or free entry.

Studies on wage negotiation mainly focus on two structures: first, an individual firm has its own independent union, or what we say decentralization wage negotiation; second, in the industrial alliance, an industrial union does wage negotiation with other firms, or what we say centralization negotiation. Under the synchronization of wage negotiation games, Horn and Wolinsky [32] and Davidson [33] found that centralization negotiation can get higher wages because of the greater bargaining power. Therefore, the workers prefer centralization of wage bargaining, while firms like decentralization wage bargaining. Bárcena-Ruiz [34] extended the game structure and considered government priority in the model to analyze some environmentally related issues; however, his study did not take into account that workers may apply different organizational structures to set wages, for example, the discussion in Ulph [35]. On the other hand, most literature on wage negotiation has also neglected the environment problem caused by pollution. To fill this research gap, Bárcena-Ruiz and Garzón [36] considered the relationship between environmental policy and labor market policy, and they also analyzed how the government sets environmental tax in international trade. The result 
indicated that in the structure of decentralization, the government will go with the environmental tax policy, which achieves better social welfare and efficiency than that in the centralization structure, but the former imposes greater damage to the environment than the latter.

In the debate on environmental policies, the impact of environmental regulations on employment is an essential issue. Hoel [37] analyzed the relationship between the labor market and environmental policies, environmental taxes, the impact of quotas, and other forms of direct regulation on employment. His study showed that if the wage is exogenous, the environmental tax, compared with other forms of environmental regulations, will lead to higher employment. Hoel [38], in the model of perfect competition and cross-border pollution, explored whether wage negotiation between firms and unions may turn out to be the reason for countries to negotiate cross-border environmental policies. He concluded that in many cases, policy consultation is not necessary. Ulph [38] showed that the producers and the government can see the environmental policies as a strategic choice; if only the producer takes strategic action, this will reduce pollution, but still cannot rule out the incentive due to the government's relaxing of environmental policy. If only one of them takes strategic action, social welfare can still be increased; on the other hand, if only the government adopts strategic action, such as pollution abatement taxation rather than setting pollution control standards, the output and the amount of pollution abatement will be increasing. Bárcena-Ruiz and Garzón [39] came up with the model with endogenous locations of firms. Their study explored how wage income influences the government's decision on its environmental policies. Because these firms will bring a positive benefit, the government still requires these polluter firms to stay in the home country even though they create pollution.

As mentioned above, there are many examples in which pollutant emissions generated by one firm negatively affect the production processes of other firms, thereby creating a detrimental externality in production. There are few papers analyzing the above question. They consider that pollutant emissions from one industry harm the marginal product of labor in another industry (for example, Copeland and Taylor [40], Benarroch and Thille [41], and Williams III [42]). In an oligopoly model of transboundary pollution, Bárcena-Ruiz [43] argued the situation when the industrial pollution from one industry hurts the labor productivity in another industry. For example, acid rain caused by heavy industry damages the labor productivity in the logging industry. He further discussed how the polluter firm adopts incomplete pollution abatement and takes advantage of different wage bargaining systems; moreover, he also probed into how the government adopts environmental pollution tax to control pollution, and how the productivity and different wage negotiation systems affect the environmental policy. However, the above paper lacks discussion on the issue of policy allocation in the pollution sector and compensation in the polluted sector. As mentioned above, when imposing welfare-improving regulation, a benevolent government may be able to tax part of the welfare gains and use the revenue to compensate affected industry for damage costs.

This research utilized the model of Bárcena-Ruiz [43], and is similarly due to negative externality, or pollution. However, we relaxed the centralized wage bargaining model of Bárcena-Ruiz [43] and then used the decentralized wage bargaining model to explore environmental policy, compensation and wage negotiations. Unlike the previous literature, which only focused on environmental taxes, this study argues that the government may subsidize the damaged firm or labor; at the same time, this study discusses the economic effects of production subsidy for the damaged firm and labor subsidy for injured labor, and furthermore compares the difference in welfare effects between emissions tax with subsidy, emissions trading and lobbying.

\section{Benchmark: Environmental Policy without Subsidy}

\subsection{The Model}

We consider that in a closed economy, there are two monopolistic industries in the domestic market. One of the industries, namely pollution industry, produces with negative externality and 
reduces the marginal productivity of labor in another industry (polluted industry). The inverse demand functions are:

$$
P_{k}=A-q_{k}, k=x, y,
$$

where $P_{k}$ is the price of industry $k, A$ is the market scale, and $q_{k}$ denotes the output quantity of industry $k$.

We assume that the firms have the same cost function $C=w_{k} L_{k}$, where $L_{k}$ is the number of employees in the firm $k$ and $w_{k}$ is the wage of the labor union $k$. This study discusses when there is negative externality, how the government levies tax to subsidize the industry hurt by pollution.

Assume that the profits of polluting industries $(x)$ and polluted industries $(y)$ are as follows:

$$
\begin{gathered}
\pi_{x}=P_{x} q_{x}-w_{x} L_{x}-t e_{x}-a_{x}^{2}, \\
\pi_{y}=P_{y} q_{y}-w_{y} L_{y} .
\end{gathered}
$$

As indicated in David and Sinclair-Desgane [44], we assume that the emission level is additively separable. For example, an investment in end-of-pipe abatement does not modify the production process and so does not affect the amount of pollution attributable to each unit produced. Following Ulph [35], the monopolistic firm of industry $x$ is making efforts in pollution abatement $a_{x}$ and the pollution abatement cost is in quadratic form, $a_{x}{ }^{2}$. The government levies environmental tax $t$ on the remaining pollution $e_{x}\left(e_{x}=q_{x}-a_{x}\right)$ and the total environmental tax levied on industry $x$ is $t e_{x}$. To highlight production inefficiency due to cross-industry pollution, we assume that the remaining pollution of $x$ industry will affect the labor productivity of $y$ industry. Following Bárcena-Ruiz [43], we have $q_{x}=L_{x}, q_{y}=L_{y} /\left(1+\beta e_{x}\right) . \beta>0$ indicates how pollution affects the productivity of industry $y$. When there is no cross-industry pollution effects, $\beta=0$.

Individual firms have their own labor union, and wages are negotiated by both sides of the labor union and the firm. We assumed the reserved wage of the labor is $w_{r}$, the utility maximization problems of labor unions are:

$$
\max _{w_{k}} U_{k}=\left(w_{k}-w_{r}\right)^{\theta} L_{k}
$$

where $\theta$ stands for how much the labor union emphasizes the wage. By following Booth [45], Haucap and Wey [46], Leahy and Montagna [47], and Lommerud et al. [48], we assume that $\theta=1$ in order to simplify the analysis. The assumptions made in the model are standard in the relevant literature (see, for example, Dobson [49], Symeonidis [50], and Bárcena-Ruiz [43]).

The social welfare function is the summation of the consumer surplus, the producer surplus, the labor union utilities and the political taxation:

$$
W=C S_{x}+C S_{y}+\pi_{x}+\pi_{y}+U_{x}+U_{y}+t e_{x}
$$

where $C S_{k}$ is consumer surplus equaling $q_{k}^{2} / 2$. Following the literature, we assume that the government's goal is to maximize social welfare. Furthermore, this study is considering a domestic environmental policy, which does not involve a negotiating stage with other countries (The standard coalition formation, as seen in the seminal papers of Carraro and Siniscalco [51], and Barrett [52], applies to all global environmental issues, such as climate change. However, in November 2016, the Paris Agreement, succeeding the Kyoto Protocol, entered into force [53-55]. The bottom-up approach of the Paris Agreement, using voluntary pledges by countries rather than top-down country or regional commitments, was quite different from the approach used earlier in the climate negotiating process at the (unsuccessful) Conference of the Parties in Copenhagen in 2009 [56]. Harstad [57] also constructs a pledge-and-review bargaining game to rationalize the key differences between the climate agreements signed in Kyoto in 1997 and Paris in 2015). For simplicity, we will focus on a cross-industry emission tax and subsidy for a benevolent government in a domestic market production and environmental policy without other countries. 
Using a three-stage game model, in the first stage, the social welfare maximization is the optimal environmental policy and subsidy on production. In the second stage, the individual labor union negotiates the optimal wage with its firm. The final stage is the monopolistic firm's production decisions. We solve the maximization problems by backward induction under the premise of Subgame Perfect Nash equilibrium (SPNE).

\subsection{Output Decision}

Firstly, we discuss the decision of the output $\left(q_{k}\right)$ in the final stage game. The firm in industry $x$ also does the pollution abatement. The first-order conditions for the profit-maximum problems are:

$$
\begin{gathered}
\frac{\partial \pi_{x}}{\partial q_{x}}=A-t-2 q_{x}-w_{x}=0, \\
\frac{\partial \pi_{x}}{\partial a_{x}}=t-2 a_{x}=0, \\
\frac{\partial \pi_{y}}{\partial q_{y}}=A-2 q_{y}-\left[1+\beta\left(q_{x}-a_{x}\right)\right] w_{y}=0 .
\end{gathered}
$$

By solving these first-order conditions, we get the output and the pollution abatement level in Equations (9)-(11):

$$
\begin{gathered}
q_{x}=\frac{1}{2}\left(A-t-w_{x}\right), \\
q_{y}=\frac{1}{4}\left[2\left(A-w_{y}\right)-\beta\left(A-w_{x}-2 t\right) w_{y}\right], \\
a_{x}=\frac{t}{2} .
\end{gathered}
$$

Taking differentiation of $q_{y}$ with respect to $\beta$, we obtain:

$$
\frac{\partial q_{y}}{\partial \beta}=\frac{-1}{4}\left(A-2 t-w_{x}\right) w_{y}<0 .
$$

We have that the higher the degree of cross-industry pollution, the lower the labor productivity of the polluted industry, and therefore the output of the polluted industries will fall.

\subsection{Wage Bargaining}

In backward solving the game problem in the second stage, we substitute the results of Equations (9)-(11) into Equation (4). The utility of the labor union can be expressed as:

$$
\begin{gathered}
U_{x}=\frac{1}{2}\left(A-t-w_{x}\right)\left(w_{x}-w_{r}\right), \\
U_{y}=\frac{1}{8}\left[2+\beta\left(A-2 t-w_{x}\right)\right]\left[2\left(A-w_{y}\right)-\beta\left(A-w_{x}-2 t\right) w_{y}\right]\left(w_{y}-w_{r}\right) .
\end{gathered}
$$

The first-order conditions are as follows:

$$
\begin{gathered}
\frac{\partial U_{x}}{\partial w_{x}}=\frac{1}{2}\left(A-t+w_{r}-2 w_{x}\right)=0, \\
\left.\frac{\partial U_{y}}{\partial w_{y}}=\frac{1}{8}\left[2+\beta\left(A-2 t-w_{x}\right)\right]\left\{2 A-2\left[2+\beta\left(A-w_{x}-2 t\right)\right] w_{y}\right]+\left[2+\beta\left(A-w_{x}-2 t\right)\right] w_{r}\right\}=0 .
\end{gathered}
$$

We obtain the optimal bargaining wages:

$$
w_{x}=\frac{1}{2}\left(A-t+w_{r}\right)
$$




$$
w_{y}=\frac{w_{r}}{2}+\frac{2 A}{4+\beta\left(A-3 t-w_{r}\right)} .
$$

Substituting the results of Equations (17) and (18) into Equations (2)-(4), we obtain:

$$
\begin{gathered}
\pi_{x}=\frac{1}{16}\left[A^{2}-2 A t+5 t^{2}-w_{r}\left(2 A-2 t-w_{r}\right)\right], \\
\pi_{y}=\frac{1}{256}\left\{4 A-w_{r}\left[4+\beta\left(A-3 t-w_{r}\right)\right]\right\}^{2}, \\
U_{x}=\frac{1}{8}\left(A-t-w_{r}\right)^{2}, \\
U_{y}=\frac{1}{128}\left\{4 A-w_{r}\left[4+\beta\left(A-3 t-w_{r}\right)\right\}^{2} .\right.
\end{gathered}
$$

Taking differentiation of $\pi_{y}$ and $U_{y}$ with respect to $\beta$, we obtain:

$$
\begin{gathered}
\frac{\partial \pi_{y}}{\partial \beta}=\frac{-1}{128}\left(A-3 t-w_{r}\right) w_{r}\left\{4 A-w_{r}\left[4+\beta\left(A-3 t-w_{r}\right)\right]\right\}<0 \\
\frac{\partial U_{y}}{\partial \beta}=\frac{-1}{4}\left(A-2 t-w_{x}\right) w_{y}<0 .
\end{gathered}
$$

As mentioned above, the higher the degree of cross-industry pollution, the lower the labor productivity of the polluted industry. At the same time, the output and the profits of the polluted industry decline. As the derived demand of labor from the polluted firm is reduced, the wages paid, the employment, and the net utility of the polluted union are also reduced.

\subsection{Environmental Policy Choices}

To maximize the social welfare, we solve the optimal environmental tax in the first stage game. Substituting the results of Equations (17) and (18) into Equation (5), and taking differentiation of $W$ with respect to $t$, we achieve the optimal emission tax as:

$$
t^{*}=\frac{\left(A-w_{r}\right)\left[16-9 \beta w_{r}\left(\beta w_{r}-4\right)\right]}{208-27 \beta^{2} w_{r}^{2}}>0 .
$$

To ensure that the output of polluted firm is positive, we assume $\beta w_{r}<\sqrt{15 / 7}$, and the second-order condition is satisfied. Taking differentiation of $t^{*}$ with respect to $\beta$, we obtain:

$$
\frac{\partial t^{*}}{\partial \beta}=\frac{36\left(A-w_{r}\right) w_{r}\left(208+\beta w_{r}\left(27 \beta w_{r}-80\right)\right)}{\left(208-27 \beta^{2} w_{r}^{2}\right)^{2}}>0 .
$$

This result indicates that the higher the externality of production, the higher the emission tax imposed by the government. The greater the externality of production, the higher the negative impact on the productivity of the polluted industry. Therefore, the government must levy a high emission tax to curb the production of the pollution sector and reduce damage.

We obtain Lemma 1 from Equation (25).

Lemma 1. The equilibrium of emission tax without subsidy

$$
\begin{gathered}
q_{x}^{*}=\frac{3\left(A-w_{r}\right)\left(32-3 \beta w_{r}\left(2+\beta w_{r}\right)\right)}{416-54 \beta^{2} w_{r}^{2}}, \\
q_{y}^{*}=\frac{2\left(A-w_{r}\right)\left(26-5 \beta w_{r}\right)}{208-27 \beta^{2} w_{r}^{2}},
\end{gathered}
$$




$$
\begin{gathered}
a_{x}^{*}=\frac{\left(A-w_{r}\right)\left(16-9 \beta w_{r}\left(\beta w_{r}-4\right)\right)}{416-54 \beta^{2} w_{r}^{2}}, \\
e_{x}^{*}=\frac{\left(A-w_{r}\right)\left(40-27 \beta w_{r}\right)}{208-27 \beta^{2} w_{r}^{2}}, \\
\pi_{x}^{*}=\frac{\left(A-w_{r}\right)^{2}\left(4736+9 \beta w_{r}\left(\beta w_{r}\left(9 \beta w_{r}\left(\beta w_{r}-2\right)-22\right)-128\right)\right)}{2\left(208-27 \beta^{2} w_{r}^{2}\right)^{2}}, \\
\pi_{y}^{*}=\frac{4\left(A-w_{r}\right)^{2}\left(26-5 \beta w_{r}\right)^{2}}{\left(208-27 \beta^{2} w_{r}^{2}\right)^{2}}, \\
U_{x}^{*}=\frac{9\left(A-w_{r}\right)^{2}\left(32-3 \beta w_{r}\left(2+\beta w_{r}\right)\right)^{2}}{2\left(208-27 \beta^{2} w_{r}^{2}\right)^{2}}, \\
U_{y}^{*}=\frac{8\left(A-w_{r}\right)^{2}\left(26-5 \beta w_{r}\right)^{2}}{\left(208-27 \beta^{2} w_{r}^{2}\right)^{2}}, \\
W^{*}=\frac{\left(A-w_{r}\right)^{2}\left(145856+\beta w_{r}\left(\beta w_{r}\left(729 \beta w_{r}\left(4+\beta w_{r}\right)-15668\right)-42944\right)\right)}{8\left(208-27 \beta^{2} w_{r}^{2}\right)^{2}} .
\end{gathered}
$$

\section{Environmental Policy with Production Subsidy}

Assuming the government levies environmental tax on polluting industry $x$ and compensates industry $y$ for pollution damage by giving unit output subsidy $s$, the profit functions can be rewritten as:

$$
\begin{gathered}
\pi_{x}=P_{x} q_{x}-w_{x} L_{x}-t e_{x}-a_{x}^{2}, \\
\pi_{y}=P_{y} q_{y}-w_{y} L_{y}+s q_{y} .
\end{gathered}
$$

The social welfare function can be rewritten as the summation of the consumer surplus, the producer surplus, the labor union utilities and the political taxation minus subsidy expenditure:

$$
W=C S_{x}+C S_{y}+\pi_{x}+\pi_{y}+U_{x}+U_{y}+t e_{x}-s q_{y} .
$$

The timing of the game is as follows. In the first stage, the government chooses the emission tax and production subsidy. In the second stage, the individual labor union negotiates the optimal wage with its firm. The final stage is the monopolistic firm's production decisions. SPNE is applied here, too.

\subsection{Output Decision}

By solving these first-order conditions, we get the output and the pollution abatement level in Equations (39)-(41):

$$
\begin{gathered}
q_{x}=\frac{1}{2}\left(A-t-w_{x}\right), \\
q_{y}=\frac{1}{4}\left[2\left(A+s-w_{y}\right)-\beta\left(A-w_{x}-2 t\right) w_{y}\right], \\
a_{x}=\frac{t}{2} .
\end{gathered}
$$

Taking differentiation of $q_{y}$ with respect to $s$, we obtain:

$$
\frac{\partial q_{y}}{\partial s}=\frac{1}{2}>0
$$


When production subsidy increases, the output of the polluted industry will be raised. Due to the production subsidy being employed, the marginal revenue of the polluted firm is increased, leading to the effect of production expansion.

\subsection{Wage Bargaining}

In backward solving the game problem in the second stage, we substitute the results of Equations (39)-(41) into Equation (4). The utility of the labor union can be expressed as:

$$
\begin{gathered}
U_{x}=\frac{1}{2}\left(A-t-w_{x}\right)\left(w_{x}-w_{r}\right), \\
U_{y}=\frac{1}{8}\left[2+\beta\left(A-2 t-w_{x}\right)\right]\left[2\left(A+s-w_{y}\right)-\beta\left(A-w_{x}-2 t\right) w_{y}\right]\left(w_{y}-w_{r}\right) .
\end{gathered}
$$

Form the first-order conditions, we obtain the optimal bargaining wages:

$$
\begin{gathered}
w_{x}=\frac{1}{2}\left(A-t+w_{r}\right), \\
w_{y}=\frac{w_{r}}{2}+\frac{2(A+s)}{4+\beta\left(A-3 t-w_{r}\right)} .
\end{gathered}
$$

Substituting the results of Equations (45) and (46) into Equations (4), (36) and (37), we obtain:

$$
\begin{gathered}
\pi_{x}=\frac{1}{16}\left[A^{2}-2 A t+5 t^{2}-w_{r}\left(2 A-2 t-w_{r}\right)\right], \\
\pi_{y}=\frac{1}{256}\left\{4(A+s)-w_{r}\left[4+\beta\left(A-3 t-w_{r}\right)\right]\right\}^{2}, \\
U_{x}=\frac{1}{8}\left(A-t-w_{r}\right)^{2}, \\
U_{y}=\frac{1}{128}\left\{4(A+s)-w_{r}\left[4+\beta\left(A-3 t-w_{r}\right)\right\}^{2} .\right.
\end{gathered}
$$

Taking differentiation of $\pi_{y}$ and $U_{y}$ with respect to $s$, we obtain:

$$
\begin{aligned}
& \frac{\partial \pi_{y}}{\partial s}=\frac{1}{32}\left\{4(A+s)-w_{r}\left[4+\beta\left(A-3 t-w_{r}\right)\right]\right\}>0, \\
& \frac{\partial U_{y}}{\partial s}=\frac{1}{16}\left\{4(A+s)-w_{r}\left[4+\beta\left(A-3 t-w_{r}\right)\right]\right\}>0 .
\end{aligned}
$$

As mentioned above, due to the production subsidy being employed, the marginal revenue of the polluted firm is increased, leading to the expansion of production. At the same time, the profits of the polluted firm increase. As the derived demand from the firm is increased, the wages paid, the employment, and the net utility of the union are also increased. Although the production subsidy is given to the firm, the labor union can extract their surplus through wage negotiation, and the union benefit will increase.

\subsection{Environmental Policy Choices}

To maximize the social welfare, we solve the optimal environmental tax and product subsidy in the first stage game. Substituting the results of Equations (45) and (46) into Equation (38), and taking differentiation of $W$ with respect to $t$ and $s$, we achieve the optimal emission tax and output subsidy as:

$$
t^{* *}=\frac{\left(A-w_{r}\right)\left(\beta w_{r}\left(4-\beta w_{r}\right)-1\right)}{3\left(1-\beta^{2} w_{r}^{2}\right)}>0
$$




$$
s^{* *}=\frac{3\left(A-w_{r}\right)\left(2-\beta w_{r}\right)}{2\left(1-\beta^{2} w_{r}^{2}\right)}>0 .
$$

Taking differentiation of $t^{* *}$ and $s^{* *}$ with respect to $\beta$, we obtain:

$$
\begin{aligned}
& \frac{\partial t^{* *}}{\partial \beta}=\frac{4\left(A-w_{r}\right) w_{r}\left(\beta w_{r}\left(\beta w_{r}-1\right)+1\right)}{3\left(1-\beta^{2} w_{r}^{2}\right)^{2}}>0, \\
& \frac{\partial s^{* *}}{\partial \beta}=\frac{3\left(A-w_{r}\right) w_{r}\left(\beta w_{r}\left(4-\beta w_{r}\right)-1\right)}{2\left(1-\beta^{2} w_{r}^{2}\right)^{2}}>0 .
\end{aligned}
$$

This result indicates that the higher the externality of production, the higher the emission tax imposed by the government, and at the same time the higher the subsidy rate for industry that are polluted. The greater the externality of production, the higher the negative impact on the productivity of the polluted industry. Therefore, the government must levy a high emission tax to curb the production of the pollution sector and reduce damage, and at the same time compensate the damaged department with higher production subsidy.

We obtain Lemma 2 from Equations (53) and (54).

Lemma 2. The equilibrium of emission tax with output subsidy

$$
\begin{gathered}
q_{x}^{* *}=\frac{\left(A-w_{r}\right)\left(2-\beta w_{r}\left(2+\beta w_{r}\right)\right)}{6\left(1-\beta^{2} w_{r}^{2}\right)}, \\
q_{y}^{* *}=\frac{\left(A-w_{r}\right)\left(2-\beta w_{r}\right)}{2\left(1-\beta^{2} w_{r}^{2}\right)}, \\
a_{x}^{* *}=\frac{\left(A-w_{r}\right)\left(\beta w_{r}\left(4-\beta w_{r}\right)-1\right)}{6\left(1-\beta^{2} w_{r}^{2}\right)}, \\
e_{x}^{* *}=\frac{\left(A-w_{r}\right)\left(1-2 \beta w_{r}\right)}{2\left(1-\beta^{2} w_{r}^{2}\right)}, \\
\pi_{x}^{* *}=\frac{\left(A-w_{r}\right)^{2}\left(5+2 \beta w_{r}\left(\beta w_{r}-1\right)\left(8+\beta w_{r}\left(\beta w_{r}-1\right)\right)\right)}{36\left(1-\beta^{2} w_{r}^{2}\right)^{2}}, \\
\pi_{y}^{* *}=\frac{\left(A-w_{r}\right)^{2}\left(2-\beta w_{r}\right)^{2}}{4\left(1-\beta^{2} w_{r}^{2}\right)^{2}}, \\
U_{x}^{* *}=\frac{\left(A-w_{r}\right)^{2}\left(\beta w_{r}\left(2+\beta w_{r}\right)-2\right)^{2}}{18\left(1-\beta^{2} w_{r}^{2}\right)^{2}}, \\
U_{y}^{* *}=\frac{\left(A-w_{r}\right)^{2}\left(2-\beta w_{r}\right)^{2}}{2\left(1-\beta^{2} w_{r}^{2}\right)^{2}}, \\
W^{* *}=\frac{\left(A-w_{r}\right)^{2}\left(\beta w_{r}\left(4+\beta w_{r}\right)-6\right)}{8\left(1-\beta^{2} w_{r}^{2}\right)} .
\end{gathered}
$$

In this case, to ensure that the pollution is positive in the equilibrium, we assume $\beta w_{r}<0.5$. Comparing the emission tax rate and social welfare between two policy pairs, we conclude that:

$$
\begin{gathered}
t^{* *}-t^{*}=-\frac{2\left(A-w_{r}\right)(128+\Omega(-362+53 \Omega))}{624-705 \Omega^{2}+81 \Omega^{4}}, \\
W^{* *}-W^{*}=-\frac{\left(A-w_{r}\right)^{2}(-8256+\Omega(10688+\Omega(-6688+\Omega(1112+\Omega(437+27 \Omega(-8+\Omega)))))}{128\left(208-235 \Omega^{2}+27 \Omega^{4}\right)} .
\end{gathered}
$$


where $\Omega=\beta w_{r}$. Due to the fact that $\beta w_{r}<0.5$, we have $t^{* *}>t^{*}$ and $W^{* *}>W^{*}$.

According to this result, we have Proposition 1.

Proposition 1. The social welfare under emission tax with production subsidy is higher than the case of emission tax without production subsidy.

This result is consistent with Bárcena-Ruiz [43]. Under a negative production externality, a positive emission tax must still be imposed. However, the importance of compensation for damaged sector is further emphasized. The economic intuition of Proposition 1 is that under a single environmental tax policy, the emission tax will reduce output, reduce consumer welfare, and deteriorate employment. The social cost of the government's emission tax is much higher, so the tax rate of the emission tax will be lower.

However, when the government adopts an emission tax with a production subsidy, the production subsidy can effectively expand the output of the polluted sector, thereby compensating for the social losses caused by the emission tax. The pollution reduced by the emission tax can effectively increase the productivity of the polluted sector, which in turn leads to an increase in the output of the polluted sector. At this point, the marginal benefit of the emission tax will increase and the emission tax rate will be increased.

Under our theoretical framework, production creates a negative externality that damages the polluted sector. An incomplete market structure leads to a low market output. Through the emission tax and production subsidies, while correcting the above distortions, the social welfare will rise accordingly.

\section{Environmental Policy with Labor Subsidy}

Assuming the government levies environmental taxes on polluting industry and compensates industry $y$ for pollution damage by giving unit labor subsidy $s$, the profit functions are shown as Equations (2) and (3).

The utility maximization problems of labor unions are:

$$
\begin{gathered}
\max _{w_{x}} U_{x}=\left(w_{x}-w_{r}\right) L_{x}, \\
\max _{w_{y}} U_{y}=\left(w_{y}-w_{r}+s\right) L_{y} .
\end{gathered}
$$

As before, the government objective function of environmental policy is the summation of the consumer surplus, the producer surplus, the union utilities and the political taxes minus subsidy expenditure:

$$
W=C S_{x}+C S_{y}+\pi_{x}+\pi_{y}+U_{x}+U_{y}+t e_{x}-s L_{y} .
$$

The timing of the game is indicated in Section 4, and SPNE is applied here, too.

\subsection{Output Decision}

By solving these first-order conditions, we get the output and the pollution abatement level in Equations (71)-(73).

$$
\begin{gathered}
q_{x}=\frac{1}{2}\left(A-t-w_{x}\right), \\
q_{y}=\frac{1}{4}\left[2\left(A-w_{y}\right)-\beta\left(A-w_{x}-2 t\right) w_{y}\right], \\
a_{x}=\frac{t}{2} .
\end{gathered}
$$




\subsection{Wage Bargaining}

By backward solving the game problem in the second stage, we substitute the results of Equations (71)-(73) into Equations (68) and (69). The utility of the labor is expressed as:

$$
\begin{gathered}
U_{x}=\frac{1}{2}\left(A-t-w_{x}\right)\left(w_{x}-w_{r}\right), \\
U_{y}=\frac{1}{8}\left[2+\beta\left(A-2 t-w_{x}\right)\right]\left[2\left(A-w_{y}\right)-\beta\left(A-w_{x}-2 t\right) w_{y}\right]\left(w_{y}-w_{r}+s\right) .
\end{gathered}
$$

Form the first-order conditions, we obtain the optimal bargaining wages:

$$
\begin{gathered}
w_{x}=\frac{1}{2}\left(A-t+w_{r}\right), \\
w_{y}=\frac{w_{r}-s}{2}+\frac{2 A}{4+\beta\left(A-3 t-w_{r}\right)} .
\end{gathered}
$$

Taking differentiation of $w_{y}$ with respect to $s$, we obtain:

$$
\frac{\partial w_{y}}{\partial s}=-\frac{1}{2}<0
$$

When labor subsidy increases, the opportunity cost of the labor supply in the polluted industry will be declined, leading to the effect of wage declined.

Substituting the results of Equations (76) and (77) into Equations (2)-(4), we obtain:

$$
\begin{gathered}
\pi_{x}=\frac{1}{16}\left[A^{2}-2 A t+5 t^{2}-w_{r}\left(2 A-2 t-w_{r}\right)\right] \\
\pi_{y}=\frac{1}{256}\left(4(A+s)+s(A-3 t) \beta-w_{r}\left(4+(A+s-3 t) \beta-\beta w_{r}\right)\right)^{2} \\
U_{x}=\frac{1}{8}\left(A-t-w_{r}\right)^{2}, \\
U_{y}=\frac{1}{128}\left(4(A+s)+s(A-3 t) \beta-w_{r}\left(4+(A+s-3 t) \beta-\beta w_{r}\right)\right)^{2} .
\end{gathered}
$$

Taking differentiation of $\pi_{y}$ and $U_{y}$ with respect to $s$, we obtain:

$$
\begin{gathered}
\frac{\partial \pi_{y}}{\partial s}=\frac{1}{128} H\left\{4(A+s)-w_{r} H+\beta w_{r}^{2}+s(A-3 t) \beta\right\}>0, \\
\frac{\partial U_{y}}{\partial s}=\frac{1}{64} H\left\{4(A+s)-w_{r} H+\beta w_{r}^{2}+s(A-3 t) \beta\right\}>0,
\end{gathered}
$$

where $H \equiv 4+\beta\left(A-3 t-w_{r}\right)$.

As mentioned above, due to the fact that the labor subsidy increases, the marginal revenue of the labor supply in the polluted industry will be increased, leading to the effect of wages becoming decreased. The marginal cost of the firm of the polluted industry decreases, leading to the effect of production expansion. At the same time, the profits of the polluted industry increases. As the derived demand from the firm is increased, the employment and the net utility of the union are also increased.

\subsection{Environmental Policy Choices}

To maximize the social welfare, we solve the optimal environmental tax and product subsidy in the first stage game. Substituting the results of Equations (76) and (77) into Equation (70), and taking differentiation of $W$ with respect to $t$ and $s$, we achieve the optimal emission tax and output subsidy as: 


$$
\begin{gathered}
t^{* * *}=\frac{\left(A-w_{r}\right)\left(\beta w_{r}\left(4-\beta w_{r}\right)-1\right)}{3\left(1-\beta^{2} w_{r}^{2}\right)}, \\
s^{* * *}=\frac{3\left(A-w_{r}\right)\left(2-\beta w_{r}\right)}{2\left(1-\beta^{2} w_{r}^{2}\right)} .
\end{gathered}
$$

We have Lemma 3 from Equations (85) and (86).

Lemma 3. The equilibrium of emission tax with labor subsidy

$$
\begin{gathered}
q_{x}^{* * *}=\frac{\left(A-w_{r}\right)\left(2-\beta w_{r}\left(2+\beta w_{r}\right)\right)}{6\left(1-\beta^{2} w_{r}^{2}\right)}, \\
q_{y}^{* * *}=\frac{\left(A-w_{r}\right)\left(2-\beta w_{r}\right)}{2\left(1-\beta^{2} w_{r}^{2}\right)}, \\
a_{x}^{* * *}=\frac{\left(A-w_{r}\right)\left(\beta w_{r}\left(4-\beta w_{r}\right)-1\right)}{6\left(1-\beta^{2} w_{r}^{2}\right)}, \\
e_{x}^{* * *}=\frac{\left(A-w_{r}\right)\left(1-2 \beta w_{r}\right)}{2\left(1-\beta^{2} w_{r}^{2}\right)}, \\
\pi_{x}^{* * *}=\frac{\left(A-w_{r}\right)^{2}\left(5+2 \beta w_{r}\left(\beta w_{r}-1\right)\left(8+\beta w_{r}\left(\beta w_{r}-1\right)\right)\right)}{36\left(1-\beta^{2} w_{r}^{2}\right)^{2}}, \\
\pi_{y}^{* * *}=\frac{\left(A-w_{r}\right)^{2}\left(2-\beta w_{r}\right)^{2}}{4\left(1-\beta^{2} w_{r}^{2}\right)^{2}}, \\
U_{x}^{* * *}=\frac{\left(A-w_{r}\right)^{2}\left(\beta w_{r}\left(2+\beta w_{r}\right)-2\right)^{2}}{18\left(1-\beta^{2} w_{r}^{2}\right)^{2}}, \\
U_{y}^{* * *}=\frac{\left(A-w_{r}\right)^{2}\left(2-\beta w_{r}\right)^{2}}{2\left(1-\beta^{2} w_{r}^{2}\right)^{2}}, \\
W^{* * *}=\frac{\left(A-w_{r}\right)^{2}\left(\beta w_{r}\left(4+\beta w_{r}\right)-6\right)}{8\left(1-\beta^{2} w_{r}^{2}\right)} .
\end{gathered}
$$

According to this result, we have Proposition 2.

Proposition 2. The social welfare distribution under production subsidy and labor subsidy is equivalence.

Proposition 2 indicates that although production subsidy is provided to the polluted firm, through wage negotiations, labor union can extract surplus from profits of the polluted firm. This effect is consistent with the direct subsidy provided by the government to the labor union.

As mentioned above, when the government subsidizes the firm, the marginal revenue of the polluted firm is increased, leading to the effect of production expansion. As the derived demand from the firm is increased, the wages paid, the employment, and the net utility of the union are also increased. Although the production subsidy is given to the firms, the labor union can extract their surplus through negotiation, and the union benefit will increase.

When the government subsidizes the labor, this increases the labor supply in the polluted industry, leading to the effect of declining wages. The marginal cost of the firm of the polluted industry decreases, leading to an increase in the output and profit of the polluted firm. In other words, the effects on the government's providing production subsidy to the polluted firm and providing wage subsidy to labor are equivalent. 


\section{Policy Extensions}

In this section, we discuss the impact of policies on environmental policy in three different scenarios. The first is that the environmental tax rate is equal to the marginal subsidy rate, the second is the equality of environmental tax revenue and subsidy expenditure, and the third is emissions trading.

\subsection{The Marginal Subsidy Rate Equivalent to the Environmental Tax Rate}

We make the environmental tax rate equal to the marginal subsidy rate, that is, $t=s$. From Proposition 2, it is shown that whatever the subsidy policy it is, production subsidy or labor subsidy, the social welfare is the same. The following analysis will only focus on the equivalence between the marginal product subsidy rate and the environmental tax rate.

The profit functions of firms are shown in Equations (96) and (97):

$$
\begin{gathered}
\pi_{x}=\left(A-q_{x}\right) q_{x}-w_{x} q_{x}-t e_{x}-a_{x}{ }^{2}, \\
\pi_{y}=\left(A-q_{y}\right) q_{y}-w_{y} q_{y}\left(1+\beta e_{x}\right)+t q_{y} .
\end{gathered}
$$

The social welfare function is as following:

$$
W=C S+\pi_{x}+\pi_{y}+U_{x}+U_{y}+t\left(e_{x}-q_{y}\right)
$$

By solving these first-order conditions, we get the output and the pollution abatement level in Equations (99)-(101).

$$
\begin{gathered}
q_{x}=\frac{1}{2}\left(A-t-w_{x}\right), \\
q_{y}=\frac{1}{4}\left[2\left(A+t-w_{y}\right)-\beta\left(A-w_{x}-2 t\right) w_{y}\right], \\
a_{x}=\frac{t}{2} .
\end{gathered}
$$

We get the optimal bargaining wages:

$$
\begin{gathered}
w_{x}=\frac{1}{2}\left(A-t+w_{r}\right), \\
w_{y}=\frac{w_{r}}{2}+\frac{2(A+t)}{4+\beta\left(A-3 t-w_{r}\right)} .
\end{gathered}
$$

The optimal emission tax and output subsidy are:

$$
\hat{t}=\hat{s}=\frac{3 \beta\left(A-w_{r}\right) w_{r}\left(24-7 \beta w_{r}\right)}{160-9 \beta w_{r}\left(8+7 \beta w_{r}\right)}>0 .
$$

By comparing product subsidy and environmental taxation, we obtain the following results:

$$
\begin{gathered}
\hat{t}-t^{* *}=\frac{2\left(A-w_{r}\right)(9 \Omega-4)(20+\Omega(2 \Omega-17))}{3\left(\Omega^{2}-1\right)(160-9 \Omega(8+7 \Omega))}>0, \\
\hat{s}-s^{* *}=3\left(A-w_{r}\right)\left(\frac{2-\Omega}{2\left(\Omega^{2}-1\right)}+\frac{\Omega(7 \Omega-24)}{9 \Omega(8+7 \Omega)-160}\right)<0,
\end{gathered}
$$

where $\Omega=\beta w_{r}$.

According to this result, we derive Proposition 3.

Proposition 3. If the environmental tax rate equals the marginal subsidy rate, we have $s^{* *}>\hat{s}$ and $\hat{t}>t^{* *}$. 
The reasoning of Proposition 3 is that since the emission tax will reduce employment and output in the pollution industry, the government prefers to give a subsidy to polluted firm and labor union in the polluted industry than to impose an emission tax. Therefore, under the separate emission tax and production subsidy, the emission tax rate is lower and the production subsidy rate is higher. However, under the emission tax equal to the production subsidy, due to the average damage of the two sectors, the emission tax will increase and the subsidy rate will decrease.

\subsection{Budget Balance of the Environmental Tax and the Subsidy}

We make the environmental tax revenue equal to the subsidy expenditure. Due to equivalence of the production subsidy and labor subsidy, we consider the case of the production subsidy only.

The profit functions of firms are shown in Equations (107) and (108):

$$
\begin{gathered}
\pi_{x}=\left(A-q_{x}\right) q_{x}-w_{x} L_{x}-t e_{x}-a_{x}{ }^{2}, \\
\pi_{y}=\left(A-q_{y}\right) q_{y}-w_{y} L_{y}+S .
\end{gathered}
$$
$S=t e_{x}$.

Here, the government compensates industry $y$ for pollution damage by giving lump sum subsidy

The government objective function of environmental policy, or the social welfare function, is the summation of the consumer surplus, the producer surplus, the total labor union utilities and the political taxation minus subsidy expenditure equal to zero:

$$
W=C S+\pi_{x}+\pi_{y}+U_{x}+U_{y} .
$$

We get the output and the pollution abatement level in Equations (110)-(112):

$$
\begin{gathered}
q_{x}=\frac{1}{2}\left(A-t-w_{x}\right), \\
q_{y}=\frac{1}{4}\left[2\left(A-w_{y}\right)-\beta\left(A-w_{x}-2 t\right) w_{y}\right], \\
a_{x}=\frac{t}{2} .
\end{gathered}
$$

By backward solving the game problem in the second stage, we substitute the results of Equations (110)-(112) into Equation (4), we have the optimal bargaining wages:

$$
\begin{gathered}
w_{x}=\frac{1}{2}\left(A-t+w_{r}\right), \\
w_{y}=\frac{w_{r}}{2}+\frac{2 A}{4+\beta\left(A-3 t-w_{r}\right)} .
\end{gathered}
$$

Substituting the results of Equations (113) and (114) into Equation (109), and solving the optimization problem, the optimal emission tax is:

$$
\widetilde{t}=\frac{\left(A-w_{r}\right)\left(16+7 \beta w_{r}\left(\beta w_{r}-4\right)\right)}{-48+21 \beta^{2} w_{r}^{2}} .
$$

With the results obtained by Equation (115), we obtain the following results:

$$
\begin{aligned}
& > \\
\widetilde{t} & =0, \text { if } \Omega \\
& <2\left(1-\sqrt{\frac{3}{7}}\right) . \\
& <
\end{aligned}
$$

According to this result, we derive Proposition 4. 
Proposition 4. If the environmental tax revenue is equal to the subsidy expenditure, we have $\widetilde{t}>0$, if $\beta w_{r}$ is relatively large.

When the policy objective is subject to budgetary constraints, the emission tax levied will be distributed to the polluted firm in a fixed amount. Emission tax or emission subsidy may occur under the maximization of social welfare subject to budgetary constraints. The reason is that, under the fixed payment, the subsidy does not have the effect on expansion of the output. When the degree of pollution damage has a high negative externality on the polluted firm and labor union, the government will levy a higher emission tax and give a positive subsidy.

Conversely, when the degree of pollution damage has a low impact on the polluted firm and labor union, in order to avoid the excessive decline in the output and employment of the polluting sector, the government's output subsidy (a negative emission tax) to the pollution sector will occur, and a lump sum tax to the polluted firm will be levied. At this time, there will be a case where the resulting distribution is deteriorated.

\subsection{Emissions Trading}

Suppose the government gives the property rights of emission to polluted firms. Assume that the emission rights are tradable, the pollution firm determines the transaction volume of emission rights $\left(e_{x}\right)$, and the polluted firm determines the price of the emission rights $(s)$. The profit functions of firms are shown in Equations (117) and (118):

$$
\begin{gathered}
\pi_{x}=\left(A-q_{x}\right) q_{x}-w_{x} L_{x}-s e_{x}-a_{x}{ }^{2}, \\
\pi_{y}=\left(A-q_{y}\right) q_{y}-w_{y} L_{y}+s e_{x} .
\end{gathered}
$$

We get the output and the pollution abatement level in Equations (119)-(121).

$$
\begin{gathered}
q_{x}=\frac{1}{2}\left(A-s-w_{x}\right), \\
q_{y}=\frac{1}{4}\left[2\left(A-w_{y}\right)-\beta\left(A-w_{x}-2 s\right) w_{y}\right], \\
a_{x}=\frac{s}{2} .
\end{gathered}
$$

By backward solving the game problem in the second stage, we substitute the results of Equations (119)-(121) into Equation (4), we have the optimal bargaining wages:

$$
\begin{gathered}
w_{x}=\frac{1}{2}\left(A-s+w_{r}\right), \\
w_{y}=\frac{w_{r}}{2}+\frac{2 A}{4+\beta\left(A-3 s-w_{r}\right)} .
\end{gathered}
$$

Substituting the results of Equations (122) and (123) into Equation (118), and solving the optimization problem, the optimal price of the emission rights is:

$$
\bar{s}=\frac{\left(A-w_{r}\right)\left(32-3 \beta w_{r}\left(\beta w_{r}-4\right)\right)}{192-9 \beta^{2} w_{r}^{2}}>0 .
$$

By comparing the price of the emission rights and the emission taxation/ output subsidy in the balanced and unbalance budget, we obtain the following results:

$$
\bar{s}-\widetilde{t}=\frac{64\left(A-w_{r}\right)\left(24+\beta w_{r}\left(-25+2 \beta w_{r}\right)\right)}{3\left(-64+3 \beta^{2} w_{r}^{2}\right)\left(-16+7 \beta^{2} w_{r}^{2}\right)}>0,
$$




$$
\bar{s}-t^{* *}=2\left(A-w_{r}\right) \frac{(48+\Omega(-122+13 \Omega))}{3\left(64-67 \Omega^{2}+3 \Omega^{4}\right)}>0 .
$$

The emission rights price set by the polluted firm is higher than the balanced budget emission tax. The main reason is that the polluted firm is the exclusive owner of the emission right. Due to the motive of maximizing profit, it will reduce the sales of emission rights and raise the price of emission rights. However, considering the damage of the employment, the profits of the firm and the consumer surplus in the polluting sector, the emission tax (the price of the emission rights set by the government in the balanced budget equilibrium) should be lower than the result set by the polluted firm. Furthermore, we find that the price of emission rights is even higher than the pollution tax under the unbalanced budget.

Comparing the profit and utility of the pollution sector between balanced budget and unbalanced budget environmental policy with production subsidy and emissions trading, we conclude that:

$$
\begin{gathered}
\bar{\pi}_{y}-\pi_{y}^{* *}=\frac{1}{4}\left(A-w_{r}\right)^{2}\left(\frac{64-12 \Omega}{192-9 \Omega^{2}}-\frac{(-2+\Omega)^{2}}{\left(-1+\Omega^{2}\right)^{2}}\right), \\
\bar{U}_{y}-U_{y}^{* *}=\frac{1}{2}\left(A-w_{r}\right)^{2}\left(\frac{16(-8+\Omega)^{2}}{\left(64-3 \Omega^{2}\right)^{2}}-\frac{(-2+\Omega)^{2}}{\left(-1+\Omega^{2}\right)^{2}}\right), \\
\bar{\pi}_{y}-\tilde{\pi}_{y}=\left(A-w_{r}\right)^{2}\left(\frac{16-3 \Omega}{192-9 \Omega^{2}}+\frac{32-2 \Omega(50+\Omega(-38+7 \Omega))}{\left(16-7 \Omega^{2}\right)^{2}}\right), \\
\bar{U}_{y}-\widetilde{U}_{y}=8\left(A-w_{r}\right)^{2}\left(\frac{(-8+\Omega)^{2}}{\left(64-3 \Omega^{2}\right)^{2}}-\frac{\left(-2+\Omega^{2}\right.}{\left(16-7 \Omega^{2}\right)^{2}}\right) .
\end{gathered}
$$

where $\Omega=\beta w_{r}$. Due to the fact that $\beta w_{r}<0.5$, we have $\tilde{\pi}_{y}<\bar{\pi}_{y}<\pi_{y}^{* *}$ and $\widetilde{U}_{y}<\bar{U}_{y}<U_{y}^{* *}$.

According to this result, we derive Proposition 5.

Proposition 5. The welfare of the polluted sector under emissions trading will be higher than the results of balanced budget environmental policy with subsidy, but lower than the results of unbalanced budget environmental policy with subsidy.

By giving emission rights to the polluted firm and allowing the polluted firm and pollution firm to trade, it is better to improve the welfare of the polluted sector than the results of balanced budget environmental policy with subsidy. The economic implication is that due to the motive of maximizing profit, the sales of emission rights will be reduced and the price of emission rights will be raised. The emission rights price set by the polluted firm will be higher than the emission tax in the balanced budget of environmental policy with subsidy. Therefore, the compensation effect of giving emission rights to the polluted firm will be better than that of the balanced budget environmental policy with subsidy.

However, the price of emission rights is higher than the pollution tax under the unbalanced budget environmental policy with subsidy. The welfare of the polluted sector is worse than the results of unbalanced budget environmental policy with subsidy. Under unbalanced budget environmental policy with subsidy, the emission tax curbs pollution and increases the marginal productivity of the polluted firm. Production subsidy increases the marginal revenue of the polluted firm and expands its output. However, giving emission rights to the polluted firm and conducting emissions trading can only inhibit pollution, but there is no output expansion effect. As a result, the welfare level of the polluted sector has declined under the emission rights trading. 


\subsection{Lobbying}

In the above framework, no group lobbies for more stringent environmental policy, although one would expect public provision of public goods to be an important aspect of domestic policies. However, the importance of lobbying groups in making environmental policies has also been emphasized by economists such as Oates and Portney [58], Carattini et al. [59], and Marchiori et al. [60] and by scholars in environmental politics (e.g., Bryner [61], and Kamieniecki [62], on the US; Markussen and Svendsen [63], and Michaelowa [64], on Europe).

To emphasize our point that the polluted industry's workers are organized in unions and lobby for compensation, we simplify our analysis, assuming the labor union of the polluted industry is the specific interest lobbying group, and the union will, through lobbying, influence the government officer's determination of optimum subsidy policy.

We assume that the information between these members of both sectors and the government officer is symmetrical. According to Berheim and Whinston's [65] and Grossman and Helpman's [66], the equilibrium policy pair should be achieved by maximizing both the government official's target function and interest group's common interest. A truthful Nash equilibrium (TNE) is applied.

The objective function for the maximization of the government officer is specified as follows:

$$
\max _{t, s} G=\alpha W(t, s)+\phi C(s),
$$

where $C(s)$ stands for the frog hair (i.e., political contributions or lobbying efforts from a firm); $G$ is the government officer's distorted target function; $\phi$ is the weight of frog hair in the government officer's target function when the union of the polluted industry devotes lobbying efforts. We also assume that for a government officer, $\phi>1$ means that one dollar of frog hair is more valuable than one dollar in the labor union's hand; $\alpha$ denotes the weight that the government places on social welfare, and $\alpha>0$.

Assume that the status quo is that the government adopts an emission tax and production subsidy. In the equilibrium with lobbying, we have $C(s)=\max \left[U(s)-U^{* *}, 0\right]$, where $U^{* *}$ is the utility under the situation that the government adopts an emission tax and production subsidy without lobbying. In TNE, we have $C(s)=U(s)-U^{* *}$. The optimal policies are determined as:

$$
\left(s^{L}, t^{L}\right)=\operatorname{argmax} G=\alpha W(t, s)+\phi U(s) .
$$

By solving the optimal problem of Equation (132), we obtain the optimal policies as:

$$
\begin{gathered}
t^{L}=\frac{\left(A-w_{r}\right)\left(-\alpha+4 \phi+\alpha \beta w_{r}\left(4-\beta w_{r}\right)\right)}{3\left(\alpha-4 \phi-\alpha \beta^{2} w_{r}^{2}\right)}, \\
s^{L}=\frac{(3 \alpha+4 \phi)\left(A-w_{r}\right)\left(2-\beta w_{r}\right)}{2 \alpha-8 \phi-2 \alpha \beta^{2} w_{r}^{2}} .
\end{gathered}
$$

The second-order conditions are required as:

$$
\begin{gathered}
\frac{\partial^{2} G}{\partial t^{2}}=\frac{9}{256}\left(-16 \alpha+(7 \alpha+4 \phi) \beta^{2} w_{r}^{2}\right)<0, \\
\frac{\partial^{2} G}{\partial s^{2}}=\frac{-1}{16}(\alpha-4 \phi)<0 .
\end{gathered}
$$

And the Hessian matrix is $|H|=\frac{9}{256} \alpha\left(\alpha-4 \phi-\alpha \beta^{2} w_{r}^{2}\right)>0$.

Taking differentiation of $t^{L}$ and $s^{L}$ with respect to $\phi$, we obtain:

$$
\frac{\partial t^{L}}{\partial \phi}=\frac{8 \alpha \beta\left(A-w_{r}\right) w_{r}\left(2-\beta w_{r}\right)}{3\left(\alpha-4 \phi-\alpha \beta^{2} w_{r}^{2}\right)^{2}}>0,
$$




$$
\frac{\partial s^{L}}{\partial \phi}=\frac{2 \alpha\left(A-w_{r}\right)\left(-2+\beta w_{r}\right)^{2}\left(2+\beta w_{r}\right)}{\left(\alpha-4 \phi-\alpha \beta^{2} w_{r}^{2}\right)^{2}}>0 .
$$

This result indicates that the higher the official places greater emphasis on the frog hair, the higher the emission tax imposed, and at the same time the higher the subsidy rate for the industry that is polluted. The higher the weight of political contributions, the greater the government's weight on the polluted industry. The higher the marginal benefit of subsidizing the polluted sector, the higher the subsidy rate. In the meanwhile, in order to reduce the damage to the polluted sector, the emission tax rate will also rise; therefore, the government must levy a high emission tax to curb the production of the pollution sector and reduce damage and furthermore, compensate the damaged department with higher production subsidy.

Under TNE, the frog hair comes from the social welfare that remains unchanged, that is, $C\left(s^{L}\right)+$ $\alpha W^{L}=\alpha W^{* *}$. The social welfare and the utility of polluted union under lobbying are shown as:

$$
\begin{gathered}
W^{L}=\frac{\left(A-w_{r}\right)^{2}\left(6 \alpha^{2}-48 \alpha \phi+32 \phi^{2}+\alpha \beta w_{r}\left(-4(\alpha-8 \phi)+\beta w_{r}\left(-7 \alpha+8 \phi+\alpha \beta w_{r}\left(4+\beta w_{r}\right)\right)\right)\right)}{8\left(\alpha-4 \phi-\alpha \beta^{2} w_{r}^{2}\right)^{2}}, \\
C\left(s^{L}\right)=\alpha W^{* *}-\alpha W^{L}=\alpha \frac{2 \phi^{2}\left(A-w_{r}\right)^{2}\left(-2+\beta w_{r}\right)^{2}}{\left(1-\beta^{2} w_{r}^{2}\right)\left(\alpha-4 \phi-\alpha \beta^{2} w_{r}^{2}\right)^{2}}>0, \\
U^{L}=\frac{\alpha^{2}\left(A-w_{r}\right)^{2}\left(-2+\beta w_{r}\right)^{2}}{2\left(\alpha-4 \phi-\alpha \beta^{2} w_{r}^{2}\right)^{2}}-C\left(s^{L}\right)=\frac{\alpha\left(A-w_{r}\right)^{2}\left(-2+\beta w_{r}\right)^{2}\left(\alpha+\frac{4 \phi^{2}}{-1+\beta^{2} w_{r}^{2}}\right)}{2\left(\alpha-4 \phi-\alpha \beta^{2} w_{r}^{2}\right)^{2}}>0 .
\end{gathered}
$$

Comparing the utility of the labor union in the polluted sector between non-lobbying and lobbying, we conclude that:

$$
U_{y}^{L}-U_{y}^{* *}=\frac{2 \phi\left(A-w_{r}\right)^{2}\left(2-\beta w_{r}\right)^{2}\left(2 \alpha-(4+\alpha) \phi+\alpha(-2+\phi) \beta^{2} w_{r}^{2}\right)}{\left(1-\beta^{2} w_{r}^{2}\right)^{2}\left(\alpha-4 \phi-\alpha \beta^{2} w_{r}^{2}\right)^{2}}>0,
$$

if $\beta w_{r}>\frac{2 \alpha-(4+\alpha) \phi}{\alpha(\phi-2)}$ and $\phi>2$.

Proposition 6. The welfare of the polluted labor union under lobby for compensation will be higher than the results of environmental policy with subsidy if the pollution damage and the weight on political contributions are sufficiently high.

Proposition 6 points out that only when the pollution damage is large enough and the officials' weight on the political contributions is strong enough, the utility of the polluted industry can be improved through lobbying compensation; otherwise, the lobbying will not be adopted. The economic reason is that when the lobbying is adopted, the emission tax and production subsidy will rise. The increase in emissions tax has led to a significant decline in employment, output, profits and consumer surplus in the polluting industry. If the damage of pollution is low, the marginal cost of raising tax by officials is quite high. At the same time, if officials do not have enough weight on political contributions, the marginal benefits of political contributions to officials will be low. The increase in production subsidy that can be spurred by lobbying and the increase in the utility of the union will be lower than the political contributions paid. The union will have no incentive to lobby.

\section{Conclusions}

This paper established a cross-industry pollution externality model. To explain a benevolent government, it may be possible to tax part of the welfare gains and use the revenue to compensate the polluted industry for the damage costs, thereby improving welfare.

We have the following conclusions: Firstly, the social welfare under emission tax with production subsidy is higher than the case of emission tax without production subsidy. Secondly, the social welfare 
distributions under production subsidy and labor subsidy are equivalent. Thirdly, under a balanced budget, the government may impose emission tax or production subsidy on the pollution sector. Fourthly, the welfare of the polluted sector under emissions trading will be higher than the results of balanced budget environmental policy with subsidy, but lower than the results of unbalanced budget environmental policy with subsidy. Finally, the welfare of the polluted labor union under lobby for compensation will be higher than the results of environmental policy with subsidy if the pollution damage and the weight on political contributions are sufficiently high.

Our paper complements the results of Bárcena-Ruiz [43]. Under a negative production externality, a positive emission tax must still be imposed and the importance of compensation (subsidization) for the damaged sector is emphasized. Production creates negative externality that damages the polluted sector and an incomplete market structure leads to low market output through emission tax and production subsidy, while correcting the distortions and increasing the social welfare. However, the welfare of the polluted sector in emission rights trading is worse than the results of unbalanced budget environmental policy with subsidy. Giving emission rights to the polluted firm and conducting emissions trading can only inhibit pollution, but there is no output expansion effect for the said firm. Emissions trading has led to a decline in the welfare of the polluted sector. In summary, the government should levy tax on the polluting industry and subsidize the industry hurt by pollution, which will effectively promote social welfare and improve welfare distribution.

Author Contributions: Conceptualization, K.-F.C., C.-S.T. and J.-Y.L.; Funding acquisition, J.-Y.L.; Investigation, C.-S.T. and C.-C.H.; Methodology, K.-F.C., C.-S.T. and C.-C.H.; Supervision, J.-Y.L.; Writing-original draft, K.-F.C. and S.-C.L.; Writing—review \& editing, T.-C.T. and J.-Y.L.

Funding: This research was funded by the Taiwan Ministry of Science and Technology with grant number [MOST 103-2410-H-151-003]. The APC was funded by National Kaohsiung University of Science and Technology, Taiwan.

Conflicts of Interest: The authors declare no conflict of interest.

\section{References}

1. BBC News. Air Pollution: Half a Million Early Deaths in Europe Despite Progress. Available online: https:/ / www.bbc.com/news/world-europe-46017339 (accessed on 7 January 2019).

2. Brunekreef, B.; Forsberg, B. Epidemiological evidence of effects of coarse airborne particles on health. Eur. Respir. J. 2005, 26, 309-318. [CrossRef] [PubMed]

3. Giere, R.; Vaughan, D.J. Minerals in the air. Elements 2013, 9, 410-411.

4. Burnett, R.T.; Pope, C.A., 3rd; Ezzati, M.; Olives, C.; Lim, S.S.; Mehta, S.; Shin, H.H.; Singh, G.; Hubbell, B.; Brauer, M.; et al. An Integrated Risk Function for Estimating the Global Burden of Disease Attributable to Ambient Fine Particulate Matter Exposure. Environ. Health Perspect. 2014, 122, 397-403. [CrossRef] [PubMed]

5. Kim, K.H.; Kabir, E.; Kabir, S. A review on the human health impact of airborne particulate matter. Environ. Int. 2015, 74, 136-143. [CrossRef] [PubMed]

6. Ma, R.; Hughes, E.; Shi, Y.; Turner, M.C.; Pope, C.A., III; Thurston, G.; Thun, M.J. Extended follow-up and spatial analysis of the American Cancer Society study linking particulate air pollution and mortality. Res. Rep. Health Eff. Inst. 2009, 140, 114.

7. Marcelli, A.; Hampai, D.; Cibin, G.; Maggi, V. Local vs. global climate change-investigation of dust from deep ice cores. Spectrosc. Eur. 2012, 24, 12-17.

8. Northcross, A.L.; Edwards, R.J.; Johnson, M.A.; Wang, Z.M.; Zhu, K.; Allen, T.; Smith, K.R. A low-cost particle counter as a realtime fine-particle mass monitor. Environ. Sci. Process. Impacts 2013, 15, 433-439. [CrossRef] [PubMed]

9. Pieters, N.; Plusquin, M.; Cox, B.; Kicinski, M.; Vangronsveld, J.; Nawrot, T.S. An epidemiological appraisal of the association between heart rate variability and particulate air pollution: A meta-analysis. Heart 2012, 98, 1127-1135. [CrossRef] [PubMed]

10. Nathan, C.; Cunningham-Bussel, A. Beyond oxidative stress: An immunologist's guide to reactive oxygen species. Nat. Rev. Immunol. 2013, 13, 349-361. [CrossRef] 
11. Liu, J.; Mauzerall, D.L.; Chen, Q.; Zhang, Q.; Song, Y.; Peng, W.; Klimont, Z.; Qiu, X.; Zhang, S.; Hu, M.; et al. Air pollutant emissions from Chinese households: A major and underappreciated ambient pollution source. Proc. Natl. Acad. Sci. USA 2016, 7756-7761. Available online: https://www.pnas.org/content/113/28/7756 (accessed on 15 December 2018). [CrossRef]

12. Gu, Y.; Wong, T.W.; Law, S.C.; Dong, G.H.; Ho, K.F.; Yang, Y.; Yim, S.H.L. Impacts of sectoral emissions in China and the implications: Air quality, public health, crop production, and economic costs. Environ. Res. Lett. 2018, 13. [CrossRef]

13. Gu, Y.; Yim, S.H.L. The air quality and health impacts of domestic trans-boundary pollution in various regions of China. Environ. Int. 2016, 97, 117-124. [CrossRef]

14. Hou, X.; Chan, C.K.; Dong, G.H.; Yim, S.H.L. Impacts of transboundary air pollution and local emissions on PM2.5 pollution in the Pearl River Delta region of China and the public health, and the policy implications. Environ. Res. Lett. 2018, in press. [CrossRef]

15. Destaillats, H.; Maddalena, R.L.; Singer, B.C.; Hodgson, A.T.; McKone, T.E. Indoor pollutants emitted by office equipment: A review of reported data and information needs. Atmos. Environ. 2008, 42, 1371-1388. [CrossRef]

16. Salma, I.; Weidinger, T.; Maenhaut, W. Time-resolved mass concentration, composition and sources of aerosol particles in a metropolitan underground railway station. Atmos. Environ. 2007, 41, 8391-8405. [CrossRef]

17. Olivier, J.G.J.; Janssens-Maenhout, G.; Muntean, M.; Peters, J.H.A.W. Trends in Global CO $\mathrm{CO}_{2}$ Emissions-2015 Report; PBL Netherlands Environmental Assessment Agency: The Hague, The Netherland, 2015.

18. European Commission. Europe 2020: Priorities. 2014. Available online: http:/ / ec.europa.eu/europe2020/ europe-2020-in-a-nutshell/priorities/index_en.htm (accessed on 27 December 2018).

19. Gozzi, F.; Della Ventura, G.; Marcelli, A.; Lucci, F. Current Status of Particulate Matter Pollution in Europe and Future Perspectives: A Review. J. Mater. Environ. Sci. 2017, 8, 1901-1909.

20. European Environmental Agency. EEA Report 5. 2015. Available online: https://www.eea.europa.eu/ publications / air-quality-in-europe-2015 (accessed on 20 December 2018).

21. Hall, M. Shift Taxes from Labour to Environment, EEA Tells Ministers. Available online: https:/ / www.euractiv.com/section/sustainable-dev/news/shift-taxes-from-labour-to-environment-eeatells-ministers / (accessed on 7 January 2019).

22. Martin, R.; Muûls, M.; De Preux, L.B.; Wagner, U.J. Industry Compensation under Relocation Risk: A Firm-Level Analysis of the EU Emissions Trading Scheme. Am. Econ. Rev. 2014, 104, 2482-2508. [CrossRef]

23. European Commission. EU Emissions Trading System. Available online: https://ec.europa.eu/clima/ policies/ets_en (accessed on 22 December 2018).

24. Pigou, A.C. The Economics of Welfare; Macmillan and Co., limited: London, UK, 1932.

25. Simpson, R.D. Optimal Pollution Taxation in a Cournot Duopoly. Environ. Resour. Econ. 1995, 6, 359-369. [CrossRef]

26. Katsoulacos, Y.; Xepapadeas, A. Environmental Policy under Oligopoly with Endogenous Market Structure. Scand. J. Econ. 1995, 97, 411-420. [CrossRef]

27. Damania, D. Pollution Taxes and Pollution Abatement in an Oligopoly Supergame. J. Environ. Econ. Manag. 1996, 30, 323-336. [CrossRef]

28. Yin, X. Corrective Taxes under Oligopoly with Inter-firm Externalities. Environ. Resour. Econ. 2003, 26, $269-277$. [CrossRef]

29. Lahiri, S.; Ono, Y. Relative Emission Standard versus Tax under Oligopoly: The Role of Free Entry. J. Econ. 2007, 91, 107-128. [CrossRef]

30. Cato, S. Emission Taxes and Optimal Refunding Schemes with Endogenous Market Structure. Environ. Resour. Econ. 2010, 46, 275-280. [CrossRef]

31. Fujiwara, K. Environmental Policies in a Differentiated Oligopoly Revisited. Resour. Energy Econ. 2009, 31, 239-247. [CrossRef]

32. Horn, H.; Wolinsky, A. Bilateral Monopolies and Incentives for Merger. Rand J. Econ. 1988, 19, 408-419. [CrossRef]

33. Davidson, C. Multiunit Bargaining in Oligopolistic Industries. J. Labor Econ. 1988, 6, 397-422. [CrossRef]

34. Bárcena-Ruiz, J.C. Politically Preferred Wage Bargaining Structures. Eur. J. Polit. Econ. 2003, 19, $341-353$. [CrossRef] 
35. Ulph, A. Environmental Policy and International Trade when Governments and Producers act Strategically. J. Environ. Econ. Manag. 1996, 30, 265-281. [CrossRef]

36. Bárcena-Ruiz, J.C.; Garzón, M.B. Environmental Taxes and Wage Setting Structure. Prague Econ. Pap. 2009, 4, 353-365. [CrossRef]

37. Hoel, M. Emission Taxes versus Other Environmental Policies. Scand. J. Econ. 1998, 100, 79-104. [CrossRef]

38. Hoel, M. Coordination of Environmental Policy for Transboundary Environmental Problems. J. Public Econ. 1997, 66, 199-224. [CrossRef]

39. Bárcena-Ruiz, J.C.; Garzón, M.B. Strategic Environmental Standards, Wage Incomes and the Location of Polluting Firms. Environ. Resour. Econ. 2003, 24, 121-139. [CrossRef]

40. Copeland, B.; Taylor, S. Trade, spatial separation, and the environment. J. Int. Econ. 1999, 47, $137-168$. [CrossRef]

41. Benarroch, M.; Thille, H. Transboundary pollution and the gains from trade. J. Int. Econ. 2001, 55, 139-159. [CrossRef]

42. Williams III, R.C. Environmental tax interactions when pollution affects health or productivity. J. Environ. Econ. Manag. 2002, 44, 261-270. [CrossRef]

43. Bárcena-Ruiz, J.C. Production Externality and Productivity of Labor. Rev. De Econ. Publica 2011, 196, 65-78.

44. David, M.; Sinclair-Desgane, B. Environmental regulation and the eco-industry. J. Regul. Econ. 2005, 28, 141-155. [CrossRef]

45. Booth, A. The Economics of the Trade Union; Cambridge University Press: New York, NY, USA, 1995.

46. Haucap, J.; Wey, C. Unionisation Structures and Innovation Incentives. Econ. J. 2004, 114, C149-C165. [CrossRef]

47. Leahy, D.; Montagna, C. Unionisation and Foreign Direct Investment: Challenging Conventional Wisdom? Econ. J. 2000, 110, C80-C92. [CrossRef]

48. Lommerud, K.E.; Meland, F; Sorgard, L. Unionised Oligopoly, Trade Liberalisation and Location Choice. Econ. J. 2003, 113, 782-800. [CrossRef]

49. Dobson, P. Multifirm unions and the incentive to adopt pattern bargaining in oligopoly. Eur. Econ. Rev. 1994, 38, 87-100. [CrossRef]

50. Symeonidis, G. Downstream merger and welfare in a bilateral oligopoly. Int. J. Ind. Organ. 2010, 28, $230-243$. [CrossRef]

51. Carraro, C.; Siniscalco, D. Strategies for the International Protection of the Environment. J. Public Econ. 1993, 52, 309-328. [CrossRef]

52. Barrett, S. Self-Enforcing International Environmental Agreements. Oxf. Econ. Pap. 1994, 46, 878-894. [CrossRef]

53. Höhne, N.; Kuramochi, T.; Warnecke, C.; Röser, F.; Fekete, H.; Hagemann, M.; Day, T.; Tewari, R.; Kurdziel, M.; Sterl, S.; et al. The Paris Agreement: resolving the inconsistency between global goals and national contributions. Clim. Policy 2017, 17, 16-32. [CrossRef]

54. Kinley, R. Climate change after Paris: from turning point to transformation. Clim. Policy 2017, 17, 9-15. [CrossRef]

55. Viñuales, J.E.; Depledge, J.; Reiner, D.M.; Lees, E. Climate policy after the Paris 2015 climate conference. Clim. Policy 2017, 17, 1-8. [CrossRef]

56. Falkner, R. The Paris Agreement and the new logic of international climate politics. Int. Aff. 2016, 92, 1107-1125. [CrossRef]

57. Harstad, B. Pledge and Review Bargaining; CESifo Working Paper 7296; Munich Society for the Promotion of Economic Research-CESifoGmbH: Munich, Germany, October 2018.

58. Oates, W.; Portney, P. The political economy of environmental policy. In Handbook of Environmental Economics; Maeler, K.-G., Vincent, J., Eds.; Elsevier: Amsterdam, The Netherland, 2003; Volume 1, pp. 325-354.

59. Carattini, S.; Levin, S.; Tavoni, A. Cooperation in the Climate Commons; Working paper no. 259; Grantham Research Institute on Climate Change and the Environment: London, UK, January 2017.

60. Marchiori, C.; Dietz, S.; Tavoni, A. Domestic Politics and the Formation of International Environmental Agreements. J. Environ. Econ. Manag. 2017, 81, 115-131. [CrossRef]

61. Bryner, G. Failure and opportunity: environmental groups in us climate policy. Environ. Polit. 2008, 17, 319-336. [CrossRef]

62. Kamieniecki, S. Corporate America and Environmental Policy: How Often Does Business Get its Way? Stanford University Press: Palo Alto, CA, USA, 2006. 
63. Markussen, P.; Svendsen, G. Industry lobbying and the political economy of GHG trade in the European Union. Energy Policy 2005, 33, 245-255. [CrossRef]

64. Michaelowa, A. Impact of interest groups on EU climate policy. Eur. Environ. 1998, 8, 152-160. [CrossRef]

65. Bernheim, B.D.; Whinston, M.D. Menu Auction, Resource Allocation, and Economic Influence. Q. J. Econ. 1986, 101, 1-31. [CrossRef]

66. Grossman, G.M.; Helpman, E. Protection for Sale. Am. Econ. Rev. 1994, 84, 833-850.

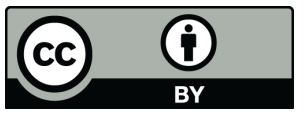

(c) 2019 by the authors. Licensee MDPI, Basel, Switzerland. This article is an open access article distributed under the terms and conditions of the Creative Commons Attribution (CC BY) license (http://creativecommons.org/licenses/by/4.0/). 